\title{
Chemopreventive effects of a Tamarindus indica fruit extract against colon carcinogenesis depends on the dietary cholesterol levels in hamsters
}

\author{
Flavia Martinello a, ${ }^{\text {, }}$ Vinicius Kannen ${ }^{\text {b, *, }}{ }^{\text {, João José Franco }}{ }^{\mathrm{b}}$, Bianca Gasparotto ${ }^{\mathrm{b}}$, \\ Juliana Yumi Sakita ${ }^{b}$, Atushi Sugohara ${ }^{c}$, Sergio Britto Garcia ${ }^{d}$, Sergio Akira Uyemura ${ }^{b}$ \\ ${ }^{a}$ Department Clinical Analysis, Federal University of Santa Catarina, Florianopolis, Brazil \\ b Department of Toxicology, Bromatology, and Clinical Analysis, University of Sao Paulo, Ribeirao Preto, Brazil \\ ${ }^{\mathrm{c}}$ Department of Animal Science, São Paulo State University, Jaboticabal, Brazil \\ ${ }^{\mathrm{d}}$ Department of Pathology, University of Sao Paulo, Ribeirao Preto, Brazil
}

\section{A R T I C L E I N F O}

\section{Article history:}

Received 18 October 2016

Received in revised form

27 June 2017

Accepted 3 July 2017

Available online 4 July 2017

\section{Keywords:}

Lipid peroxidation

Oxidative stress

Cholesterol

Tamarind

Hypercholesterolemia

Antioxidant potential

\begin{abstract}
A B S T R A C T
Tamarind has significant antioxidant potential. We showed that tamarind protects hypercholesterolemic hamsters from atherosclerosis. Hypercholesterolemia might increase the risk of colon cancer. We investigated whether tamarind extract modulates the risk of colon cancer in hypercholesterolemic hamsters. Hamsters $(n=64)$ were given tamarind and a hypercholesterolemic diet for 8 weeks. The groups were the control, tamarind treatment, hypercholesterolemic, and hypercholesterolemic treated with tamarind groups. Half of each group was exposed to the carcinogen dimethylhydrazine (DMH) at the 8th week. All hamsters were euthanatized at the 10th week. In carcinogen-exposed hypercholesterolemic hamsters, tamarind did not alter the cholesterol or triglyceride serum levels, but it reduced biomarkers of liver damage (alanine transaminase [ALT], and aspartate aminotransferase [AST]). Tamarind decreased DNA damage in hepatocytes, as demonstrated by analysis with an anti- $\gamma \mathrm{H} 2 \mathrm{~A} . \mathrm{X}$ antibody. In liver and serum samples, we found that this fruit extract reduced lipid peroxidation (thiobarbituric acid reactive substances [TBARS]) and increased endogenous antioxidant mechanisms (glutathione peroxidase $[\mathrm{GPX}]$ and superoxide dismutase [SOD]). However, tamarind did not alter either lipid peroxidation or antioxidant defenses in the colon, which contrasts with DMH exposure. Moreover, tamarind significantly increased the stool content of cholesterol. Although tamarind reduced the risk of colon cancer in hypercholesterolemic hamsters that were carcinogenically exposed to DMH by $63.8 \%$ (Metallothionein), it was still $\sim 51 \%$ higher than for animals fed a regular diet. Staining colon samples with an anti- $\gamma \mathrm{H} 2 \mathrm{~A}$.X antibody confirmed these findings. We suggest that tamarind has chemoprotective activity against the development of colon carcinogenesis, although a hypercholesterolemic diet might impair this protection.
\end{abstract}

๑) 2017 Elsevier Ltd. All rights reserved.

\section{Introduction}

Various healing properties have been reported about Tamarindus indica L. (T. indica; tamarind), such as digestive, carminative, laxative, expectorant, tonic, antioxidant, hypolipemic, antiatherosclerotic, antioxidant, antihepatotoxic, anti-inflammatory,

\footnotetext{
* Corresponding author. Department of Toxicology, Bromatology, and Clinical Analysis, University of Sao Paulo, 14040-903 Brazil.

E-mail address: vinicius.kannen@fcfrp.usp.br (V. Kannen).

${ }^{1}$ Authors contributed equally.
}

antimutagenic, and antidiabetic properties (Komutarin et al., 2004; Maiti et al., 2004; Martinello et al., 2006; Ramos et al., 2003; Rimbau et al., 1999). Our previous report showed that a T. indica fruit had approximately $34.02 \pm 2.11 \mathrm{nM} / \mathrm{ml}$ of polyphenols and $35.51 \pm 5.61 \mu \mathrm{g} / \mathrm{ml}$ of flavonoids (Martinello et al., 2006). Owen and colleagues profiled antioxidants in T. indica pericarp and seeds. They found that $73 \%$ of the phenolic antioxidants in pericarp were proanthcyanidins, while procyanidins were largely found in seeds (Sudjaroen et al., 2005). Recently, other research groups supported these findings that $T$. indica is rich in antioxidant compounds (Escalona-Arranz et al., 2016; Natukunda et al., 2016). Notably, we 
found that $T$. indica reduces the risk of atherosclerosis in hypercholesterolemic hamsters (Martinello et al., 2006).

However, the effects of natural compounds on colon carcinogenesis are controversial (Femia et al., 2003; Millen et al., 2007; Nalini et al., 2006; Shi et al., 2010). For instance, T. indica was previously found to promote pro-carcinogenic effects on colon tissue (Shivshankar and Shyamala Devi, 2004). Colon cancer is the third most common malignancy worldwide (Siegel et al., 2014). It affects over 1.2 million people in the USA, and prospective data suggest $\sim 150$ thousand patients will be newly diagnosed per year going forward (Siegel et al., 2012). Previous reports suggested that fatty acids and their metabolites promote free radical-induced DNA damage, which enhances the risk of colon cancer (Chithra and Leelamma, 2000; Cruse et al., 1979). Colon carcinogenesis develops through a multi-step sequence of changes (Fearon and Vogelstein, 1990), which means that colon tumors might arise from preneoplastic lesions (Bird, 1987; Fearon and Vogelstein, 1990; Maurin et al., 2007). Mutations and deletions in the colonic epithelial cellular DNA are the earliest changes that induce the development of colon cancer tumors (Maurin et al., 2007). In terms of whether phosphorylation on serine 139 of histone $2 \mathrm{AX}(\gamma-\mathrm{H} 2 \mathrm{AX})$ signals the genomic machinery that a DNA damage event is taking place (Lobrich and Jeggo, 2007), new evidence demonstrated that this phosphorylated protein is the gold standard biomarker to study genomic damage (Orthwein et al., 2014). It seems that when colonocytes undergo massive and protracted DNA damage, histological modifications in colonic glands become detectable and have been named aberrant crypt foci (ACF) (Bird, 1987). Another biomarker, named metallothionein (MT), was shown to precisely determine the intensity of early carcinogenic events in the colon (Mori et al., 2012). Many preneoplastic lesions classically increase the risk of colon cancer because exposure to carcinogens promotes genomic instability and aberrant cell growth, leading to tissue transformation (Bird, 1995; Bird and Good, 2000; McLellan et al., 1991). High-expression of novel biomarkers, such as MT and $\gamma$ $\mathrm{H} 2 \mathrm{AX}$, demonstrates the risk of colon cancer resembles the development of ACF (Frajacomo et al., 2015).

Hamsters are the best animal models to study the effects of dietary cholesterol, which might illustrate the effects of hypercholesterolemia in humans (Lim et al., 2013; Martinello et al., 2006). Although a single report suggested that hamsters do not endure colon carcinogenesis after exposure to dimethylhydrazine (DMH) (Jeong and Kamino, 1993), there has been strong evidence indicating otherwise (Moore et al., 1987; Paulsen et al., 1996); for example, DMH in hamster drinking water was reported to induced angiosarcomas in the liver, lungs, muscle, heart, and pancreas (Toth, 1972). Paulsen et al. observed that DMH injections induce colon preneoplastic lesions in two different hamster strains (Paulsen et al., 1996). Additionally, Moore et al. demonstrated that hamsters exposed to DMH develop hepatic and hemangiocellular liver lesions, forestomach papillomas, and colon adenocarcinomas (Moore et al., 1987). Therefore, exposure of hypercholesterolemic hamsters to carcinogens seems a reasonable experimental model to evaluate the modulation of colon cancer risk with any hypocholesterolemic treatment.

Given that it seems odd an antioxidant-rich fruit, such as T. indica (Escalona-Arranz et al., 2016; Martinello et al., 2006; Natukunda et al., 2016; Sudjaroen et al., 2005), has been found to delay the development of renal cell carcinoma in rats (VargasOlvera et al., 2012) while promoting colon cancer (Shivshankar and Shyamala Devi, 2004), further investigation is required. Hence, we explored whether the antioxidant activity of $T$. indica could reduce the risk of colon cancer in hypercholesterolemic hamsters.

\section{Methods}

\subsection{Preparation of tamarind fruit extracts}

According to our previous report (Martinello et al., 2006), tamarind fruits (100 g) were macerated in $70 \%$ alcohol $(300 \mathrm{ml}$; $4{ }^{\circ} \mathrm{C} ; 72 \mathrm{~h}$ ). Filtration and evaporation were used to remove the alcohol from the whole tamarind fruit extract. Before each treatment, dried tamarind extracts (5\%) were diluted in water.

\subsection{Experimental design}

Sixty-four Golden Syrian male hamsters ( $\pm 115 \mathrm{~g} ; 30$ days) were acclimatized for two weeks before starting the experiment ( 5 hamsters/plastic cage; $25 \pm 2{ }^{\circ} \mathrm{C}$; 12 -12 h light-dark). The experiments followed the approved protocol by the Animal Care and Use Ethical Committee ( $\mathrm{n}^{\circ}$ 05.1.590.53.0). Hamsters were randomly divided into 4 groups (each group had 16 hamsters) at the beginning of the current experiments. These 4 groups were named standard diet (CT; Table 1), treatment with $T$. indica extract (TI), hypercholesterolemic diet (CL; full description of this diet is given below), and hypercholesterolemic diet plus tamarind treatment (TI-CL). After 56 days from the first day of tamarind treatment, half of the initial four groups (resulting in 8 groups with 8 hamsters each) were exposed to the carcinogen dimethylhydrazine (DMH; $30 \mathrm{mg} / \mathrm{kg}$; single subcutaneous injection). At the end of the 10th experimental week, all 8 groups were euthanized. All hamsters had free access to food and liquids throughout the 10 weeks.

A hypercholesterolemic diet (CL) was prepared by adding $1 \%(\mathrm{w} /$ w) cholesterol (92.5\%; VETEC, Sigma-Aldrich, DE; V900415) to the standard chow (CT; Guabi Nutrilabor, Mogiana Food Industry, Brazil; Table 2). Briefly, CT pellets were milled before cholesterol was added and re-pelleting. After drying hypercholesterolemic pellets, each $300 \mathrm{~g}$ was vacuum sealed in dark containers and stored at $4{ }^{\circ} \mathrm{C}$, which was repeated weekly.

\subsection{Sacrifice}

All hamsters were weighed at the beginning and end of the current experiment. Hamsters were sacrificed in a $\mathrm{CO}_{2}$ chamber. Blood was collected by cardiac puncture and, centrifuged at $3,000 \mathrm{~g}$ for $10 \mathrm{~min}$. In individual autopsies, the liver and colon were carefully but quickly removed. Samples were homogenized according to our previous description (Martinello et al., 2006). Liver and colon samples were also fixed in $10 \%$ buffered formalin for $24 \mathrm{~h}$.

\subsection{Histopathological analysis}

After paraffin-embedded colon samples had been sectioned at thickness of $4 \mu \mathrm{m}$, they were stained with H\&E. According to our

Table 1

Composition of standard diet.

\begin{tabular}{llll}
\hline $\begin{array}{l}\text { General } \\
\text { compounds }\end{array}$ & $\%$ & Specific compounds & Amount \\
\hline Carbohydrate & 52 & Niacin & $80 \mathrm{mg}$ \\
Protein & 22 & Calcium* & $50 \mathrm{mg}$ \\
Fat & 4 & Folic Acid & $3 \mathrm{mg}$ \\
Fiber & 8 & Biotin & $0.1 \mathrm{mg}$ \\
Calcium & 1.2 & Choline & $1200 \mathrm{mg}$ \\
Phosphorus & 0.8 & & \\
Other Minerals & 10 & & \\
Vitamin Mix & 2 & & \\
Other compounds & 0.01 & & \\
\hline
\end{tabular}

Standard diet (CT). Values are given for each 1000 g. *Calcium Pantothenate. 
Table 2

Initial and final body weight values, and weight gain.

\begin{tabular}{|c|c|c|c|c|c|c|c|}
\hline \multirow[t]{2}{*}{ Period } & \multirow[t]{2}{*}{ Carcinogen } & \multicolumn{4}{|l|}{ Treatment } & \multirow[t]{2}{*}{ Comparison } & \multirow[t]{2}{*}{$\mathrm{P}<$} \\
\hline & & $\mathrm{CT}$ & $\mathrm{TI}$ & $\mathrm{CL}$ & TI-CL & & \\
\hline Initial & No-DMH & $138.4 \pm 16.7$ & $133.9 \pm 15.6$ & $123.4 \pm 20$ & $122 \pm 23.9$ & ${ }^{*} v s \mathrm{CT}$ & $*^{* * *} 0.001$ \\
\hline (g) & $\mathrm{DMH}$ & $130.1 \pm 17.4$ & $135.6 \pm 16.6$ & $129.3 \pm 19.5$ & $128.7 \pm 20.1$ & ${ }^{\S} v s \mathrm{TI}$ & ${ }^{*} 0.05$ \\
\hline Final & No-DMH & $160.7 \pm 11.8$ & $167.1 \pm 8.7$ & $163.2 \pm 7.5$ & $168.4 \pm 11.8$ & & ${ }^{\S} 0.05$ \\
\hline$(\mathrm{g})$ & $\mathrm{DMH}$ & $145.1 \pm 18.4$ & $143.3 \pm 11.3$ & $139.9 \pm 9.8$ & $147.1 \pm 9.5$ & & \\
\hline \multirow[t]{2}{*}{ Weight Gain } & No-DMH & $0.31 \pm 0.07$ & $0.47 \pm 0.09^{*}$ & $0.56 \pm 0.17^{* * *}$ & $0.66 \pm 0.26^{\S}$ & & \\
\hline & $\mathrm{DMH}$ & $0.21 \pm 0.14$ & $0.11 \pm 0.07$ & $0.15 \pm 0.13$ & $0.26 \pm 0.15$ & & \\
\hline
\end{tabular}

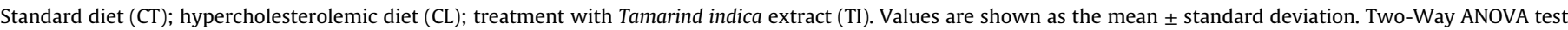
(Bonferroni post hoc test) was used for all comparisons from both initial and final measurements. Weight gain $=($ initial-final/total days).

previous description (Kannen et al., 2012a), aberrant crypts with dysplastic features were enumerated under light microscopy at $400 \times$ magnification (Fig. 1A). The ratio of aberrant crypts per $\sim 100$ normal glands illustrated the risk of colon cancer.

Primary antibodies were applied to stain $4-\mu \mathrm{m}$ paraffinembedded sections according to the manufacturer's instructions. These antibodies were anti-MT [clone FL-61 (1:100); Santa Cruz Biotechnology, Santa Cruz, California, USA] and anti- $\gamma$ H2A.X [clone 3F2 (1:200); Abcam, Burlingame, California, USA]. Afterward, tissue sections were counterstained with Harris's hematoxylin. The ratio of positive MT crypts per total number of colonic glands validated the data from histopathologically determined to be aberrant crypts. The number of positive $\gamma$ H2A.X colonocytes per crypt demonstrated the intensity of DNA damage in colon samples. In the liver, this DNA damage intensity was determined to be the number of positive $\gamma$ H2A.X hepatocytes per microscopic field.

\subsection{Biochemical analyses}

Total cholesterol (mg/dL), triglyceride (mg/dL), high-density lipoprotein (HDL; mg/dL), low-density lipoprotein (LDL; mg/dL), alanine transaminase (ALT; U/L), and aspartate aminotransferase (AST; U/L) levels were measured in serum samples (triplicate) according to standard methods previously reported (Friedewald et al., 1972; Warnick et al., 1982) (Abbott VP Super System Autoanalyzer [Abbot, US]; commercial enzymatic kit [Labtest, Brazil]). A further description was previously reported (Martinello et al., 2006).

\subsection{Fecal cholesterol content}

Fecal cholesterol levels were analyzed in stool samples (1 g) according to a previous description (Ntanios and Jones, 1999). Briefly, a gas-liquid chromatography with a flame ionization detector (GLC; HP 5890 Series II, Hewlett Packard, US) and capillary column (SAC-5; Supelco, US) was used. Samples were first mixed to the internal standard compound $5 \alpha$-cholestane $(0.2 \mathrm{mg} / \mathrm{g})$. Saponification was then performed with $0.5 \mathrm{M}$ methanolic $\mathrm{KOH}$ $\left(1 \mathrm{~h} ; 100{ }^{\circ} \mathrm{C}\right)$. Then, distilled water and petroleum-ether were added to samples cooled at room temperature. Non-saponifiable materials at the upper solution layer were dried with liquid nitrogen and resuspended in hexane $(300 \mu \mathrm{l})$. This mixture was injected into the GLC for analysis $(2 \mu \mathrm{L})$. Identification peaks were confirmed with phytosterol (Sigma, US). Values are expressed as mg/dL.

\subsection{Determination of a lipid peroxidation reaction and antioxidant enzyme levels in serum, colon, and liver samples}

First, tissue samples were homogenized in ice-cold potassium phosphate buffer with a Potter-Elvehjem homogenizer. Centrifugation was then performed at $13,000 \mathrm{~g}\left(4 \mathrm{~min} ; 4^{\circ} \mathrm{C}\right)$. For each of the following analyses, a full description was previously reported (Martinello et al., 2006).

\subsubsection{Thiobarbituric acid reactive substances (TBARS)}

TBARS activity $(\mathrm{nM} / \mathrm{g}$ ) represented the total lipid peroxidation in serum and tissue samples. Before the first incubation $\left(6 \mathrm{~h} ; 37^{\circ} \mathrm{C}\right)$, a reaction buffer $\left(\mathrm{KCl}[125 \mathrm{mmol} / \mathrm{L}] ; \mathrm{C}_{8} \mathrm{H}_{18} \mathrm{~N}_{2} \mathrm{O}_{4} \mathrm{~S} / \mathrm{KOH}\right.$ [50 mmol/L]) was added to the samples. Then, the starting buffer was added (Fe $\left.\left[\mathrm{NH}_{4}\right]_{2}\left[\mathrm{SO}_{4}\right]_{2}[50 \mu \mathrm{M} / \mathrm{L}] ; \mathrm{Na}_{3} \mathrm{C}_{6} \mathrm{H}_{5} \mathrm{O}_{7}[2 \mathrm{mM} / \mathrm{L}]\right)$. Centrifugation $(1,900 \mathrm{~g} ; 10 \mathrm{~min})$ was performed after lipid and protein precipitation $\left(\mathrm{H}_{2} \mathrm{SO}_{4}[12 \mathrm{~N}] ; \mathrm{H}_{3} \mathrm{PW}_{12} \mathrm{O}_{40}[10 \%]\right)$. The pellet was resuspended in distilled water and $\mathrm{C}_{4} \mathrm{H}_{4} \mathrm{~N}_{2} \mathrm{O}_{2} \mathrm{~S}(1 \%)$, which was kept at $95{ }^{\circ} \mathrm{C}$ for
A

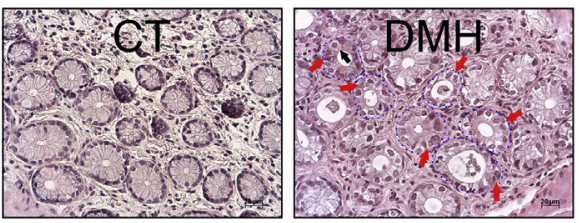

B

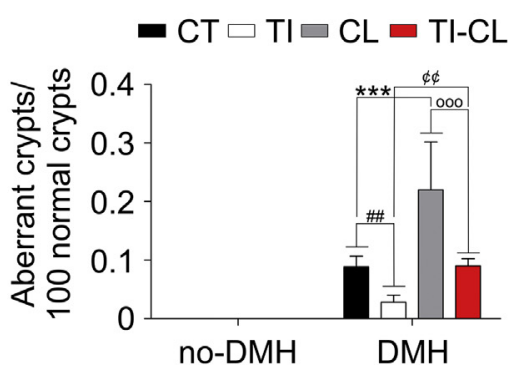

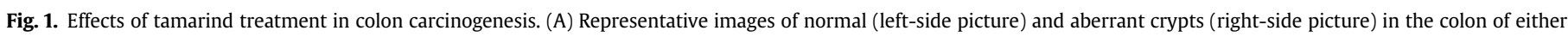

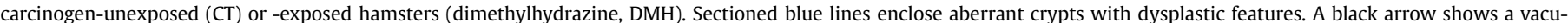

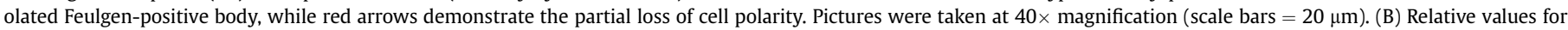

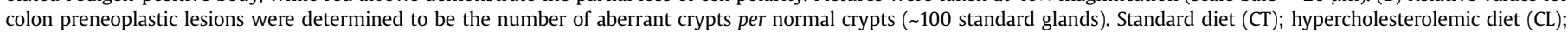

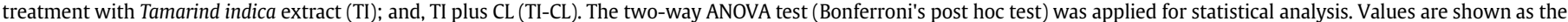

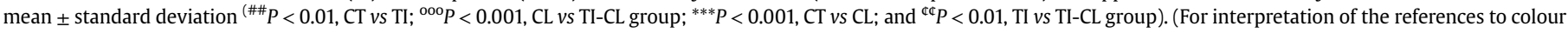
in this figure legend, the reader is referred to the web version of this article.) 
$1 \mathrm{~h}$. Extraction with $\mathrm{C}_{4} \mathrm{H}_{9} \mathrm{OH}$ was performed in cooled samples at room temperature (Kannen et al., 2013). The reactions were finally analyzed (UV 515/553 nm wavelengths) in a Hitachi F4500 fluorimeter (Hitachi, US). Values were expressed as $\mu \mathrm{M} / \mathrm{g}$ or $\mathrm{mL}$.

\subsubsection{Glutathione peroxidase (GPx)}

A spectrophotometrical analysis (340 nm) was applied to determine the GPx activity. Samples were first mixed in the reaction buffer $\left(\mathrm{KH}_{2} \mathrm{PO}_{4}\left[0.1 \mathrm{M} / \mathrm{L} ; \mathrm{pH}\right.\right.$ 7.0]; $\mathrm{C}_{21} \mathrm{H}_{26} \mathrm{~N}_{7} \mathrm{Na}_{4} \mathrm{O}_{17} \mathrm{P}_{3} \cdot \mathrm{xH}_{2} \mathrm{O}$ [NADPH; $0.2 \mathrm{mM} / \mathrm{L}] ;\left[(\mathrm{HOOCCH})_{2} \mathrm{NCH}_{2} \mathrm{CH}_{2}\right]_{2} \mathrm{NCH}_{2} \mathrm{COOH}[1 \mathrm{mM} /$ L]; GSH [1.5 mM/L]; and GR [7.3 $\left.\times 10^{-6} \mathrm{U} / \mathrm{mL}\right]$. The starting buffer (tBuOOH $[0.12 \mathrm{mM} / \mathrm{L}]$ ) was added afterwards (Flohe and Gunzler, 1984). Values were expressed as $\mu \mathrm{M} / \mathrm{min} / \mathrm{g}$ or $\mathrm{mL}$.

\subsubsection{Catalase (CAT)}

Spectrophotometrical analysis determined the CAT activity in all samples. Samples were mixed with the reaction buffer $\left(\mathrm{H}_{2} \mathrm{O}_{2}\right.$ [30 mM/L]; $\mathrm{KH}_{2} \mathrm{PO}_{4}$ [50 mM/L]; pH 7.0), which was then analyzed (Aebi, 1984). Values were expressed as $\mathrm{mM} / \mathrm{L}$ of consumed $\mathrm{H}_{2} \mathrm{O}_{2}$ $\left(\mathrm{CH}_{2} \mathrm{O}_{2} / \mathrm{min}\right)$ per $\mathrm{g}$ or $\mathrm{mL}$.

\subsubsection{Superoxide dismutase (SOD)}

SOD activity was measured by spectrophotometrical analysis (340 nm). Reaction buffer $\left(\mathrm{HN}\left[\mathrm{CH}_{2} \mathrm{CH}_{2} \mathrm{OH}\right]_{2}[100 \mathrm{mM} / \mathrm{L}]\right.$; NADPH $[0.14 \mathrm{mM} / \mathrm{L}] ; \quad\left[\mathrm{HO}_{2} \mathrm{CCH}_{2}\right]_{2} \mathrm{NCH}_{2} \mathrm{CH}_{2} \mathrm{~N}\left[\mathrm{CH}_{2} \mathrm{CO}_{2} \mathrm{H}\right]_{2} / \mathrm{MnCl}_{2} \quad[2.27 /$ $1.14 \mathrm{mM} / \mathrm{L} ; \mathrm{pH}$ 7.0]) was first added to the samples. NADPH oxidation was started with $\mathrm{HSCH}_{2} \mathrm{CH}_{2} \mathrm{OH}(1 \mathrm{mM} / \mathrm{L})$ for analysis (Paoletti and Mocali, 1990). Values for the SOD activity (U/g or $\mathrm{mL}$ ) were based on a standard curve (IC50 [NADPH oxidation inhibitions] $=\mathrm{U}$ [one SOD unit]).

\subsection{Statistical analysis}

Data were analyzed with the two-way ANOVA test (Bonferroni's post hoc test) using GraphPad Prism 5 (GraphPad Software, US). This statistical test enables different categorical independent endpoints to be analyzed on one dependent variable. Statistical significance was set at $\mathrm{p}<0.05$. All values are reported as the mean \pm standard deviation.

\section{Results}

\subsection{Cholesterol alters the chemoprotective effects of T. indica in the} intestinal colon

Here, we investigated whether a tamarind fruit extract might modify the risk of colon cancer. We observed that hamsters endured well the current experiments (Tables 2 and 3). Although the final weight did not significantly change within groups exposed to $\mathrm{DMH}$, carcinogen-unexposed hamsters treated with TI and CL gained more weight than control hamsters (Table 2). While the food intake remained unchanged, hamsters given TI drank fewer liquids than the controls (Table 3).

Histopathological analysis revealed tamarind reduced the development of dysplastic aberrant crypts (Fig. 1B). However, a careful statistical analysis showed that a hypercholesterolemic diet increased the risk of colon cancer in both tamarind-treated and -untreated groups that were carcinogenically exposed to $\mathrm{DMH}$ (Fig. 1B). We validated these results by staining colon samples with an anti-MT antibody, which is a biomarker linked to the development of preneoplastic lesions in this tissue (Frajacomo et al., 2015; Mori et al., 2012). It not only confirmed that tamarind has anticarcinogenic effects but also demonstrated that a hypercholesterolemic diet impairs the benefits of this fruit (Fig. 2A). Phosphorylation on serine 139 of that histone 2AX $(\gamma-\mathrm{H} 2 \mathrm{AX})$ is broadly studied to determine the carcinogenic DNA double-strand breaks [DSB (Lobrich and Jeggo, 2007);]. This analysis supported that the chemoprotective effects of tamarind are impaired by increasing the dietary cholesterol intake (Fig. 2B; CT vs CL $[P<0.001]$; TI vs TI-CL $[P<0.001])$. Then, we biochemically analyzed the cholesterol levels in stool content and found this lipid compound was highly increased by tamarind in both DMH-exposed and unexposed hamsters (Fig. 2C). The dietary cholesterol content seems to impair some chemoprotective effects of tamarind fruit extract.

\subsection{T. indica protects the liver from hypercholesterolemia- and carcinogen-induced lipid peroxidation}

Given that small bowel uptake of cholesterol alters hepatic metabolism (Iqbal and Hussain, 2009), we biochemically analyzed several biomarkers to determine the further effects of tamarind extract in hamsters fed a hypercholesterolemic diet. According to Table 5 , this dietary regimen increased the serum cholesterol levels in both carcinogenic exposed and unexposed groups. Moreover, carcinogenic exposure impaired the anticholesterolemic effects of tamarind. Fruit extract decreased the triglyceride levels in DMHunexposed hamsters (Table 4). Although tamarind augmented the HDL concentrations in experimental groups that were not exposed to $\mathrm{DMH}$, it did not protect hamsters against hypercholesterolemia and carcinogenic exposure (Table 4). Only carcinogen-unexposed hamsters showed reduced serum LDL levels with fruit extract treatment (Table 4). When biomarkers of liver damage were analyzed (ALT and AST), we found that potential damaging effects of $\mathrm{DMH}$ were counteracted by treating hypercholesterolemic hamsters with tamarind (Table 4).

To verify these events, we biochemically analyzed liver samples. Table 5 shows that hypercholesterolemic hamsters that were carcinogenically exposed to DMH had reduced hepatic lipid peroxidation when treated with tamarind. Although this fruit extract increased the hepatic levels of that scavenging enzyme GPx against lipid hydroperoxides, hypercholesterolemia reduced the intensity of these effects (Table 5). Tamarind extract only increased the hepatic content of CAT in normal hamsters (Table 5). In carcinogen-

Table 3

Daily food and water intakes.

\begin{tabular}{|c|c|c|c|c|c|c|c|}
\hline \multirow[t]{2}{*}{ Type } & \multirow[t]{2}{*}{ Carcinogen } & \multicolumn{4}{|c|}{ Treatments } & \multirow[t]{2}{*}{ Comparison } & \multirow[t]{2}{*}{$\mathrm{P}<$} \\
\hline & & $\mathrm{CT}$ & TI & $\mathrm{CL}$ & TI-CL & & \\
\hline $\begin{array}{l}\text { Food } \\
\text { (g/day) } \\
\text { Liquids } \\
\text { (ml/day) }\end{array}$ & $\begin{array}{l}\text { No-DMH } \\
\text { DMH } \\
\text { No-DMH } \\
\text { DMH }\end{array}$ & $\begin{array}{l}48 \pm 4 \\
45 \pm 6 \\
138 \pm 46 \\
135 \pm 36\end{array}$ & $\begin{array}{l}43 \pm 11 \\
47 \pm 9 \\
60 \pm 19^{* * *} \\
55 \pm 21^{* * *}\end{array}$ & $\begin{array}{l}50 \pm 1 \\
46 \pm 4 \\
122 \pm 51^{\S \S} \\
130 \pm 49^{\S \S \S}\end{array}$ & $\begin{array}{l}49 \pm 4 \\
47 \pm 8 \\
58 \pm 21^{\circ \circ} \\
60 \pm 17^{\circ 0 \circ}\end{array}$ & $\begin{array}{l}{ }^{*} v s \mathrm{CT} \\
{ }^{\S} v s \mathrm{TI} \\
{ }^{\circ} v s \mathrm{CL}\end{array}$ & $\begin{array}{l}{ }^{* * *} 0.001 \\
{ }^{\S} 0.01 \\
{ }^{\S \S} 0.001 \\
{ }^{\circ} 0.01 \\
{ }^{\circ \circ} 0.001\end{array}$ \\
\hline
\end{tabular}

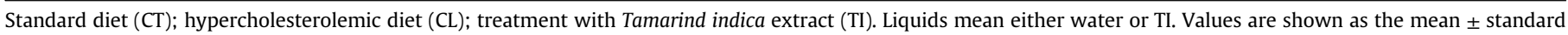
deviation. Two-Way ANOVA test (Bonferroni post hoc test) was applied for data analysis. 
A
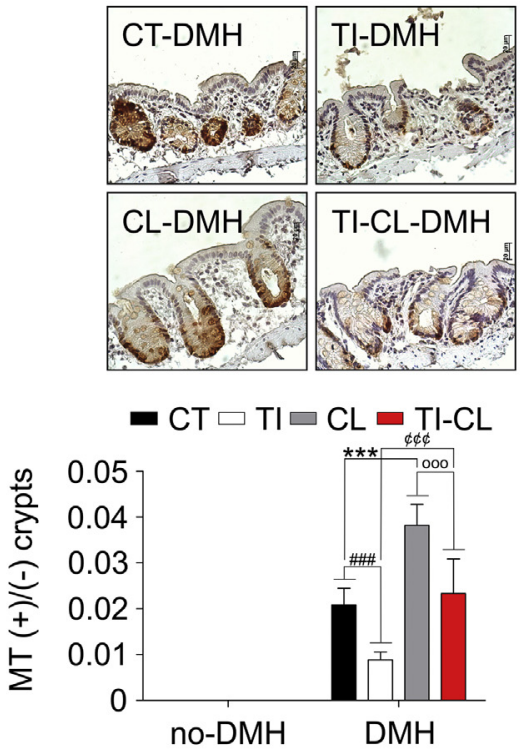

C

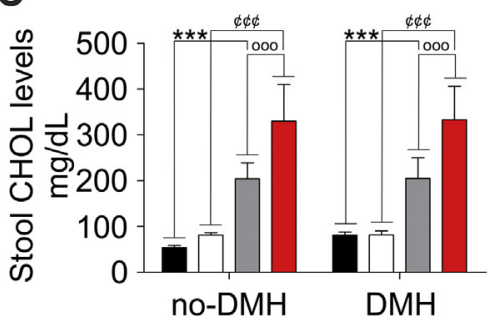

B

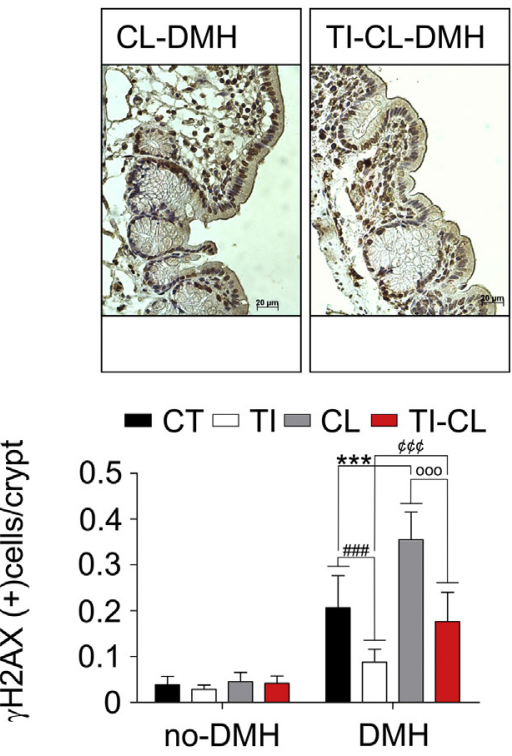

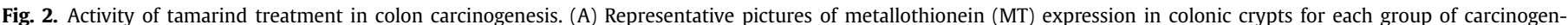

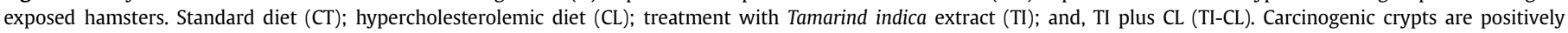

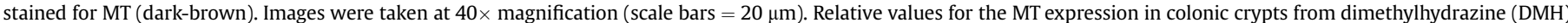

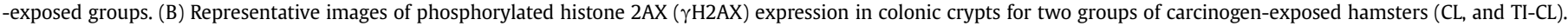

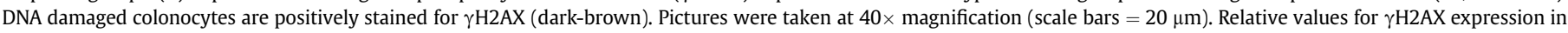

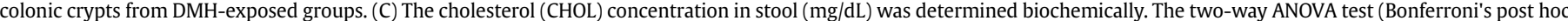

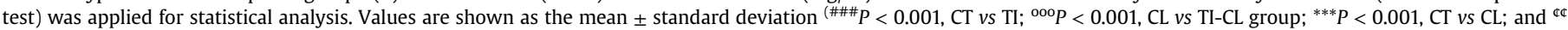
${ }^{\circledR} P<0.001$, TI vs TI-CL group). (For interpretation of the references to colour in this figure legend, the reader is referred to the web version of this article.)

unexposed and -exposed groups, cholesterol seems to impair the tamarind-related increase in hepatic SOD levels (Table 5).

Then, we histopathologically analyzed liver samples for DSB with an anti- $\gamma-\mathrm{H} 2 \mathrm{AX}$ antibody (Fig. 3A). Although tamarind protects carcinogenically exposed hepatocytes from DNA damage in both dietary experimental conditions, cholesterol seem to interfere with its hepatic benefits (Fig. 3B). These findings might illustrate that tamarind protects hepatic functions from damage, while cholesterol might weaken its activity.

\subsection{T. indica modulates serum lipid peroxidation, but not colonic lipid peroxidation}

Table 7 reveals that the serum SOD levels were increased in control hamsters treated with tamarind. A hypercholesterolemic diet and carcinogenic exposure impaired this positive effect of tamarind (Table 6). Although tamarind increased the serum CAT levels in hamsters fed a regular diet and exposed to DMH, cholesterol blocked its protective activity (Table 6). Tamarind only improved enzymatic protection against lipid peroxidation in $\mathrm{DMH}-$ unexposed hamsters (Table 6), while cholesterol negatively impacted its protective effects (Table 6). Finally, we found that tamarind extract did not protect from the DMH-related impairment in antioxidant enzyme levels or promotion of lipid peroxidation in the intestinal colon (Table 7). Tamarind failed to improve the tissue antioxidant capacity of the intestinal colon.

\section{Discussion}

We treated hypercholesterolemic hamsters that were carcinogenically exposed with tamarind to reduce their lipid peroxidation and thus the risk of colon cancer. Our findings suggest that the benefits of tamarind in colon carcinogenesis might be related to its hepatic protection against lipid peroxidation. Of note, subcutaneous exposure to DMH promotes its slow release into the bloodstream, which is followed by hepatic lipid peroxidation throughout metabolic activation (Rajeshkumar and Kuttan, 2003). Specifically, hepatic CYP2E1 metabolizes DMH into azoxymethane (AOM), which later becomes methylazoxymethanol (MAM). Colonocytes then metabolize MAM into methyl diazonium ion, as well as methyl cation, that binds and damages DNA (Rosenberg et al., 2009). Another report showed that DMH promotes lipid peroxidation and malignant transformation in the colon (Dudeja and Brasitus, 1990). Indeed, dietary cholesterol promoted lipid peroxidation and colon adenomas, reducing the tissue antioxidant capacity in $\mathrm{DMH}-$ exposed rats (Tseng et al., 1996). On the other hand, tamarind has 
Table 4

Serum fat acids and fecal cholesterol levels.

\begin{tabular}{|c|c|c|c|c|c|c|c|}
\hline \multirow[t]{2}{*}{ Analysis } & \multirow[t]{2}{*}{ Carcin } & \multicolumn{4}{|l|}{ Treatments } & \multirow[t]{2}{*}{ Comp } & \multirow[t]{2}{*}{$\mathrm{P}<$} \\
\hline & & $\mathrm{CT}$ & $\mathrm{TI}$ & $\mathrm{CL}$ & TI-CL & & \\
\hline \multirow[t]{2}{*}{$\begin{array}{l}\mathrm{CHOL} \\
\mathrm{mg} / \mathrm{dL}\end{array}$} & No-DMH & $153 \pm 22.8$ & $125 \pm 13.4^{*}$ & $\begin{array}{l}259 \pm 34.2 \\
* * *\end{array}$ & $\underset{\substack{1 \\
\infty \infty 0}}{129.8 \pm 11.9}$ & \multirow{12}{*}{$\begin{array}{l}{ }^{*} v s \mathrm{CT} \\
{ }^{\circ} \text { vs CL } \\
{ }^{\S} \text { vs TI }\end{array}$} & $\begin{array}{l}{ }^{*} 0.05 \\
{ }_{* * *}^{*} 0.001\end{array}$ \\
\hline & $\mathrm{DMH}$ & $173.3 \pm 8.6$ & $158.9 \pm 13$ & $202.6 \pm 28.6^{*}$ & $192.5 \pm 24.8$ & & ${ }^{\circ} 0.01$ \\
\hline \multirow[t]{2}{*}{$\begin{array}{l}\text { TG } \\
\mathrm{mg} / \mathrm{dL}\end{array}$} & No-DMH & $380 \pm 74.2$ & $\begin{array}{l}183 \pm 29.5 \\
* * * *\end{array}$ & $\begin{array}{l}520 \pm 74.8 \\
* * *\end{array}$ & $204 \pm 25.9$ & & $\begin{array}{l}{ }^{\circ \circ} 0.001 \\
s^{s} 0.001\end{array}$ \\
\hline & $\mathrm{DMH}$ & $286.3 \pm 64.7$ & $219.6 \pm 48.2$ & $\begin{array}{l}476 \pm 111.2 \\
* * *\end{array}$ & $\underset{\S \S, 000}{337.1 \pm 82.6}$ & & ${ }^{\S} 0.01$ \\
\hline \multirow[t]{2}{*}{$\begin{array}{l}\mathrm{HDL} \\
\mathrm{mg} / \mathrm{dL}\end{array}$} & No-DMH & $48.2 \pm 8.7$ & $\begin{array}{l}81.5 \pm 3.1 \\
* * *\end{array}$ & $45.3 \pm 4.4$ & $\underset{\circ \infty}{73.2} \pm 5.2$ & & \\
\hline & $\mathrm{DMH}$ & $52.6 \pm 7.4$ & $\begin{array}{l}67 \pm 8.4 \\
* *\end{array}$ & $57.4 \pm 6.9$ & $65.5 \pm 13.5$ & & \\
\hline LDL & No-DMH & $108.6 \pm 25$ & $52.3 \pm 20.1^{* * *}$ & $214.6 \pm 34.7^{* * *}$ & $56.6 \pm 12.2^{\circ \circ \circ}$ & & \\
\hline $\mathrm{mg} / \mathrm{dL}$ & $\mathrm{DMH}$ & $127 \pm 26.3$ & $94.9 \pm 10.3$ & $145.3 \pm 33.6$ & $118 \pm 44.9$ & & \\
\hline ALT & No-DMH & $50.1 \pm 12$ & $36.7 \pm 8$ & $40 \pm 4$ & $39.8 \pm 6.4$ & & \\
\hline $\mathrm{U} / \mathrm{L}$ & $\mathrm{DMH}$ & $72.7 \pm 25.8$ & $69.8 \pm 24$ & ${ }_{* * *}^{157.2} \pm 36.6$ & $114.1 \pm 14.9$ \$\$§,००० & & \\
\hline AST & No-DMH & $44.4 \pm 14.4$ & $44.1 \pm 17.6$ & $41.8 \pm 18.3$ & $35.6 \pm 9.3$ & & \\
\hline $\mathrm{U} / \mathrm{L}$ & $\mathrm{DMH}$ & $91.6 \pm 13.6$ & $90.5 \pm 5.9$ & $\underset{* * *, \S \S \S}{170.9} \pm 43.3$ & $127.8 \pm 36.9 \S \S, \circ \circ$ & & \\
\hline
\end{tabular}

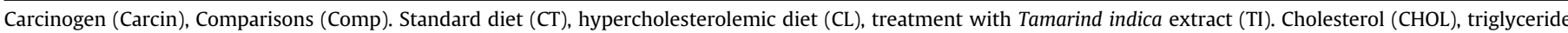

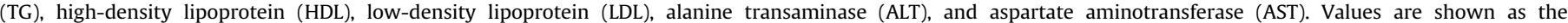
mean \pm standard deviation. Two-Way ANOVA test (Bonferroni post hoc test) was applied for data analysis.

Table 5

Hepatic oxidative stress.

\begin{tabular}{|c|c|c|c|c|c|c|c|}
\hline \multirow[t]{2}{*}{ Analysis } & \multirow[t]{2}{*}{ Carcin } & \multicolumn{4}{|l|}{ Treatments } & \multirow[t]{2}{*}{ Comp } & \multirow[t]{2}{*}{$\mathrm{P}<$} \\
\hline & & $\mathrm{CT}$ & TI & $\mathrm{CL}$ & $\mathrm{TI}-\mathrm{CL}$ & & \\
\hline TBARS & No-DMH & $601.7 \pm 70.1$ & $559.5 \pm 100.1$ & $634.6 \pm 70.8$ & $601.4 \pm 68.7$ & ${ }^{*} v s \mathrm{CT}$ & ${ }^{* *} 0.01$ \\
\hline$\mu \mathrm{M} / \mathrm{g}$ & $\mathrm{DMH}$ & $1084.7 \pm 111.2$ & $996.1 \pm 107.9$ & $1472.8 \pm 151.2 * * *$ & $\underset{\circ \infty, 8 \S 9}{1309.6 \pm 99.7}$ & $\begin{array}{l}{ }^{\circ} v s \mathrm{CL} \\
{ }^{\S} v s\end{array}$ & $\begin{array}{l}{ }^{* * *} 0.001 \\
{ }^{\circ \circ} 0.001\end{array}$ \\
\hline \multirow[t]{2}{*}{$\begin{array}{l}\mathrm{GPx} \\
\mu \mathrm{M} / \mathrm{min} / \mathrm{g}\end{array}$} & No-DMH & $148.1 \pm 4.3$ & $\begin{array}{l}218.6 \pm 4.3 \\
* * *\end{array}$ & $146.8 \pm 1.9$ & $\underset{\circ \infty .}{187.1} \pm 3.2$ & $\mathrm{TI}$ & $\begin{array}{l}{ }^{\circ} 0.01 \\
{ }^{\circ} 0.05\end{array}$ \\
\hline & $\mathrm{DMH}$ & $140.8 \pm 1.8$ & $\begin{array}{l}165.3 \pm 4.5 \\
* *\end{array}$ & $136 \pm 3.4$ & 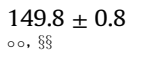 & & $\begin{array}{l}{ }^{\S \S} 0.001 \\
{ }^{\S} 0.01\end{array}$ \\
\hline \multirow{4}{*}{$\begin{array}{l}\mathrm{CAT} \\
\mathrm{mM} / \mathrm{L}-\mathrm{CH}_{2} \mathrm{O}_{2} / \mathrm{min} / \mathrm{g} \\
\mathrm{SOD} \\
\mathrm{U} / \mathrm{g}\end{array}$} & No-DMH & $1.2 \pm 0.1$ & $1.9 \pm 0.1^{* * *}$ & $1.2 \pm 0.1$ & $1.3 \pm 0.1$ & & \\
\hline & $\mathrm{DMH}$ & $1.1 \pm 0.1$ & $1.3 \pm 0.1$ & $1.1 \pm 0.1$ & $1.2 \pm 0.1$ & & \\
\hline & No-DMH & $327.3 \pm 31.3$ & $371.3 \pm 20.3^{* *}$ & $\begin{array}{l}259.2 \pm 25.8 \\
* * *\end{array}$ & $\underset{\S \S \S}{278.4} \pm 21.7$ & & \\
\hline & $\mathrm{DMH}$ & $299.6 \pm 32.2$ & $325.3 \pm 30.3$ & $\begin{array}{l}246.4 \pm 22.4 \\
* * *\end{array}$ & $\underset{\circ, \S \S}{281.2} \pm 18$ & & \\
\hline
\end{tabular}

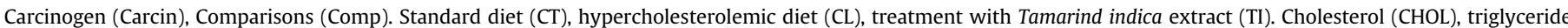

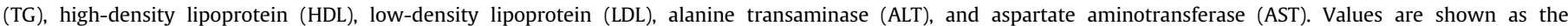
mean \pm standard deviation. Two-Way ANOVA test (Bonferroni post hoc test) was applied for data analysis.

A

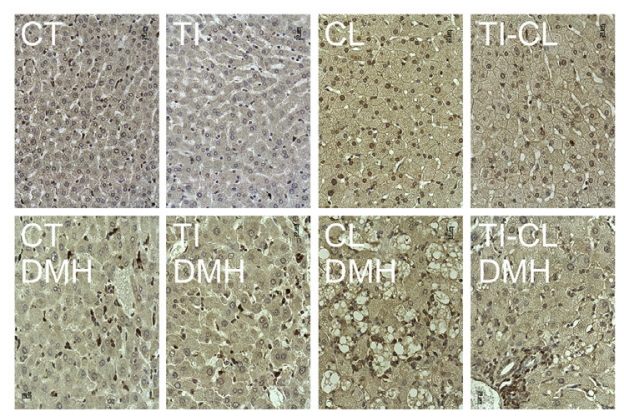

B

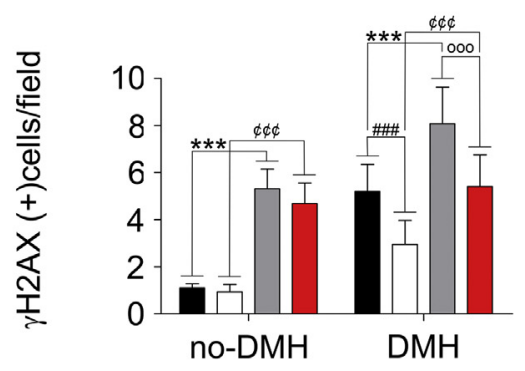

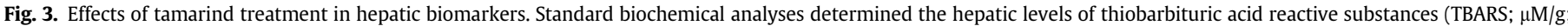

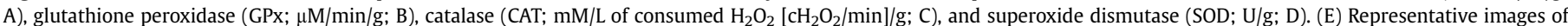

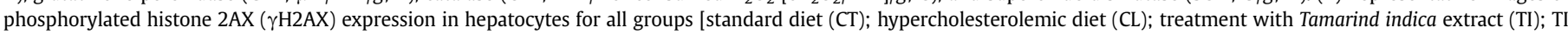

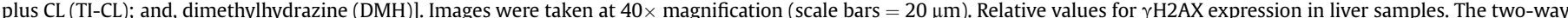

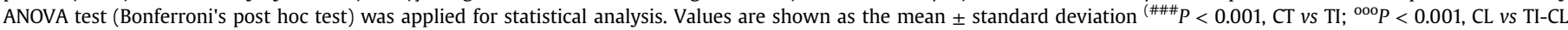
group; ${ }^{* * *} P<0.001$, CT $v s \mathrm{CL}$; and ${ }^{\dddot{*}} \mathrm{P}<0.001$, TI vs TI-CL group). 
Table 6

Serum oxidative stress.

\begin{tabular}{|c|c|c|c|c|c|c|c|}
\hline \multirow[t]{2}{*}{ Analysis } & \multirow[t]{2}{*}{ Carcin } & \multicolumn{4}{|l|}{ Treatments } & \multirow[t]{2}{*}{ Comp } & \multirow[t]{2}{*}{$\mathrm{P}<$} \\
\hline & & $\mathrm{CT}$ & TI & $\mathrm{CL}$ & $\mathrm{TI}-\mathrm{CL}$ & & \\
\hline \multirow[t]{2}{*}{$\begin{array}{l}\mathrm{SOD} \\
\mathrm{U} / \mathrm{mL}\end{array}$} & No-DMH & $14.5 \pm 1.8$ & $\begin{array}{l}18 \pm 0.9 \\
* * *\end{array}$ & $\begin{array}{l}6.3 \pm 1 \\
* * *\end{array}$ & $6.6 \pm 0.5$ & \multirow{8}{*}{$\begin{array}{l}{ }^{*} v s \mathrm{CT} \\
{ }^{\circ} v s \mathrm{CL} \\
{ }^{\S} v s \mathrm{TI}\end{array}$} & \multirow{8}{*}{ 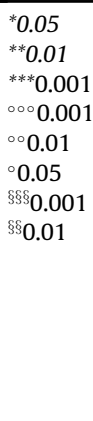 } \\
\hline & $\mathrm{DMH}$ & $10.4 \pm 1.4$ & $11.4 \pm 1$ & $10 \pm 1$ & $9.2 \pm 0.7$ & & \\
\hline \multirow[t]{2}{*}{$\begin{array}{l}\mathrm{CAT} \\
\mathrm{mM} / \mathrm{L}-\mathrm{CH}_{2} \mathrm{O}_{2} / \mathrm{min} / \mathrm{mL}\end{array}$} & No-DMH & $0.023 \pm 0.008$ & $0.03 \pm 0.005$ & $0.017 \pm 0.0046$ & $\underset{\S \S}{0.02} \pm 0.0035$ & & \\
\hline & $\mathrm{DMH}$ & $0.014 \pm 0.007$ & $\begin{array}{l}0.024 \pm 0.007 \\
*\end{array}$ & $0.011 \pm 0.004$ & $0.014 \pm 0.003$ & & \\
\hline \multirow[t]{2}{*}{$\begin{array}{l}\mathrm{GPx} \\
\mu \mathrm{M} / \mathrm{min} / \mathrm{mL}\end{array}$} & No-DMH & $9.36 \pm 0.7$ & $10.8 \pm 0.2$ & $8.8 \pm 0.36$ & $\underset{\circ \circ, 85}{9.7 \pm 0.46}$ & & \\
\hline & $\mathrm{DMH}$ & $5.8 \pm 0.34$ & $6.1 \pm 0.2$ & $5.5 \pm 0.5$ & $5.9 \pm 0.15$ & & \\
\hline \multirow[t]{2}{*}{$\begin{array}{l}\text { TBARS } \\
\mu \mathrm{M} / \mathrm{mL}\end{array}$} & No-DMH & $5.2 \pm 0.2$ & $4.37 \pm 0.3$ & $\begin{array}{l}7.2 \pm 0.3 \\
* * *\end{array}$ & $\begin{array}{l}5.8 \pm 0.2 \\
\circ \circ \circ, \S \S \S\end{array}$ & & \\
\hline & DMH & $7 \pm 0.09$ & $6.6 \pm 0.2$ & $8.8 \pm 0.4^{*}$ & $7.7 \pm 0.2^{\circ \circ, 3 \S}$ & & \\
\hline
\end{tabular}

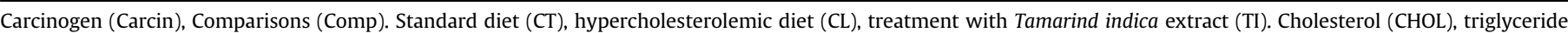

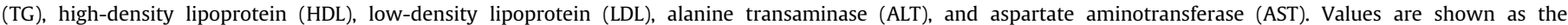
mean \pm standard deviation. Two-Way ANOVA test (Bonferroni post hoc test) was applied for data analysis.

Table 7

Colon oxidative stress.

\begin{tabular}{|c|c|c|c|c|c|c|c|}
\hline \multirow[t]{2}{*}{ Analysis } & \multirow[t]{2}{*}{ Carcin } & \multicolumn{4}{|l|}{ Treatments } & \multirow[t]{2}{*}{ Comp } & \multirow[t]{2}{*}{$\mathrm{P}<$} \\
\hline & & $\mathrm{CT}$ & TI & $\mathrm{CL}$ & $\mathrm{TI}-\mathrm{CL}$ & & \\
\hline TBARS & No-DMH & $221.1 \pm 13.1$ & $211.3 \pm 10$ & $230.2 \pm 16$ & $213.8 \pm 11.2$ & None & None \\
\hline $\mathrm{nM} / \mathrm{g}$ & $\mathrm{DMH}$ & $249 \pm 11.6$ & $242.2 \pm 23.1$ & $245.8 \pm 20$ & $244.6 \pm 19$ & & \\
\hline GPX & No-DMH & $151.4 \pm 9.8$ & $149.3 \pm 8$ & $147.4 \pm 11$ & $140.2 \pm 10.3$ & & \\
\hline$\mu \mathrm{M} / \mathrm{min} / \mathrm{g}$ & $\mathrm{DMH}$ & $129.2 \pm 9.7$ & $128 \pm 11.2$ & $127.8 \pm 12$ & $130 \pm 13$ & & \\
\hline CAT & No-DMH & $0.41 \pm 0.05$ & $0.4 \pm 0.04$ & $0.44 \pm 0.03$ & $0.42 \pm 0.03$ & & \\
\hline $\mathrm{mM} / \mathrm{l}-\mathrm{CH}_{2} \mathrm{O}_{2} / \mathrm{min} / \mathrm{g}$ & $\mathrm{DMH}$ & $0.25 \pm 0.02$ & $0.2 \pm 0.03$ & $0.24 \pm 0.03$ & $0.23 \pm 0.02$ & & \\
\hline SOD & No-DMH & $150.2 \pm 12.3$ & $161 \pm 12$ & $142.8 \pm 10.9$ & $153.4 \pm 14.6$ & & \\
\hline $\mathrm{U} / \mathrm{g}$ & $\mathrm{DMH}$ & $82.1 \pm 6.9$ & $90.2 \pm 9$ & $79.7 \pm 7.1$ & $77.1 \pm 5.2$ & & \\
\hline
\end{tabular}

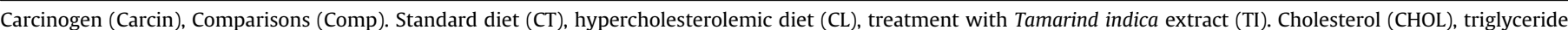

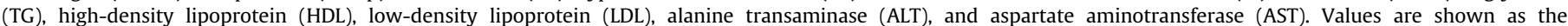
mean \pm standard deviation. Two-Way ANOVA test (Bonferroni post hoc test) was applied for data analysis.

significant free radical scavenging activity due to its large content of polyphenols and flavonoids, which provides its treated subject with a considerable level of antioxidants. Moreover, tamarind also seemed to augment the endogenous activity of antioxidant molecules such as GPx, SOD, and CAT (Martinello et al., 2006). Treating $\mathrm{H}_{2} \mathrm{O}_{2}$-challenged hepatic human cells with tamarind, Razali et al. confirmed that this fruit increased the endogenous antioxidant enzymes that we previously described (Martinello et al., 2006; Razali et al., 2015).

Although it seems exciting that tamarind reduced the risk of colon cancer, we should clearly state that cholesterol impaired the chemoprotective effects, as DNA-damaging events were not decreased compared to those in hamsters fed a regular diet. Hence, we should consider how dietary cholesterol acted procarcinogenically in the current experimental model. Adding 1\% cholesterol to a regular diet increased, respectively, in 2.5-fold and 1.7-fold the stool content of this lipid compound and DNAdamaging process in colonic epithelial cells in DMH-exposed hamsters. While this carcinogen reduced the circulating cholesterol levels in hypercholesterolemic hamsters 1.7-fold, increasing the dietary cholesterol content augmented hepatic tissue damage 4-fold and 2.3-fold in lipid peroxidation. These observations suggest that dietary cholesterol might promote the development of colon carcinogenesis, enhancing lipid peroxidation in liver and colon tissues. Previously, we showed that dietary restriction alters hepatic metabolism, promoting lipid peroxidation and the risk of colon cancer (Kannen et al., 2013). Furthermore, rats fed a $14.6 \%$ lard-enriched diet had augmented abdominal and visceral adipose tissues and a higher risk of colon cancer (Kannen et al., 2012b). Another report from our group revealed that the surgical ablation of visceral adipose tissues reduced the development of colon carcinogenesis (Kannen et al., 2014).

Comparing groups treated with tamarind fed either a regular or hypercholesterolemic diet revealed that tamarind increased the release of cholesterol $\sim 4$-fold, while it doubled DNA-damaging events in carcinogenically hamsters. These findings demonstrate the benefits and limitations of tamarind treatment, which protects from the worsening activity of cholesterol without decreasing the risk of colon cancer to control rates. Although cholesterol impaired the benefits of tamarind treatment, tamarind has more benefits than a commercial drug named orlistat, which augments the stool content of cholesterol. We reported that orlistat increased the risk of colon cancer in rats given a high-fat diet (Garcia et al., 2006). In contrast, with tamarind, orlistat seems to lack some antioxidant capacity at the hepatic and systemic levels (Garcia et al., 2006; Morales et al., 2016). For instance, Gottteland and colleagues showed that the prebiotic oligofructose improved the intestinal flora activity, protecting patients from the damaging effects of orlistat, such as changes in inflammatory, oxidative, and metabolic events, at the systemic level (Morales et al., 2016).

The current findings also revealed that tamarind did not improve the antioxidant mechanism in the intestinal colon, which seems to clarify why this fruit was previously found to be unable to reduce MNU-induced preneoplastic lesions (Shivshankar and Shyamala Devi, 2004). Whether chemoprotective effects of tamarind are centered in the hepatic metabolism (Martinello et al., 
2006; Razali et al., 2015), this fruit could not counteract the direct carcinogenic effects of MNU (Shivshankar and Shyamala Devi, 2004) because it does not require any activation by the hepatic metabolism (Zarbl et al., 1985). A potential limitation of our study is that we were unable to evaluate the findings of Atawodi and Spiehelhalder in TI given to hamsters. These authors reported that out of 27 tropical plants, T. indica had the most primary amines and that harmful methylamine had the highest levels (Atawodi and Spiegelhalder, 1994). However, this previous study did not describe whether samples were collected in areas free of anthropogenic contaminants, which could be a bias of the reported data. A recent investigation showed that soil contamination increases the content of carcinogens in vegetables used as food by Nigerians (Inam et al., 2016). Here, tamarind fruits were collected from trees in the Brazilian countryside and were free of anthropogenic pollutants.

Taken together, we suggest that the tamarind extract has some chemoprotective effects against the development of colon carcinogenesis. However, we advocate for careful consideration because tamarind was unable to fully protect from the carcinogenic promoter activity of cholesterol in the colon. Further studies are warranted on this topic.

\section{Conflict of interest}

The authors declare that they have no conflicts of interest.

\section{Competing interest}

None.

\section{Ethics approval}

The ethical approved protocol \#05.1.590.53.0 was a large project coordinated by Prof. Dr. Sergio Akira Uyemura. Some data (serum and liver samples; AST, ALT, glucose, total cholesterol, HDL, LDL, TG, TBARS, CAT, SOD, and GPX) from carcinogen-unexposed groups (STD groups [extract treated and untreated hamsters], and HCD groups [extract treated and untreated hamsters]) were already published (Martinello et al., 2006). These previous findings are used as control groups in this study. All experiments of carcinogenunexposed and -exposed groups were performed together.

\section{Acknowledgments}

We thank R. O. Lopes, A. Zanardo Filho and N.M.F. Rodrigues for their excellent technical assistance. Financial support was provided by the São Paulo Research Foundation (FAPESP; 02/03174-5) and National Council for Scientific and Technological Development (CNPq; 475276/01-9). The funders had no role in the study design, data collection, analysis, decision to publish, or manuscript preparation.

\section{Transparency document}

Transparency document related to this article can be found online at http://dx.doi.org/10.1016/j.fct.2017.07.005.

\section{References}

Aebi, H., 1984. Catalase in vitro. Methods Enzym. 105, 121-126.

Atawodi, S.E., Spiegelhalder, B., 1994. Precursors of N-nitroso compounds in some Nigerian medicinal plants. Cancer Lett. 79, 107-115.

Bird, R.P., 1987. Observation and quantification of aberrant crypts in the murine colon treated with a colon carcinogen: preliminary findings. Cancer Lett. 37, $147-151$.
Bird, R.P., 1995. Role of aberrant crypt foci in understanding the pathogenesis of colon cancer. Cancer Lett. 93, 55-71.

Bird, R.P., Good, C.K., 2000. The significance of aberrant crypt foci in understanding the pathogenesis of colon cancer. Toxicol. Lett. 112-113, 395-402.

Chithra, V., Leelamma, S., 2000. Coriandrum sativum-effect on lipid metabolism in 1,2-dimethyl hydrazine induced colon cancer. J. Ethnopharmacol. 71, 457-463.

Cruse, P., Lewin, M., Clark, C.G., 1979. Dietary cholesterol is co-carcinogenic for human colon cancer. Lancet 1, 752-755.

Dudeja, P.K. Brasitus, T.A., 1990.1,2-Dimethylhydrazine-induced alterations in lipid peroxidation in preneoplastic and neoplastic colonic tissues. Biochim. Biophys. Acta 1046, 267-270.

Escalona-Arranz, J.C., Perez-Roses, R., Rodriguez-Amado, J., Morris-Quevedo, H.J., Mwasi, L.B., Cabrera-Sotomayor, O., Machado-Garcia, R., Fong-Lorez, O., Alfonso-Castillo, A., Puente-Zapata, E., 2016. Antioxidant and toxicological evaluation of a Tamarindus indica L. leaf fluid extract. Nat. Prod. Res. 30, 456-459.

Fearon, E.R., Vogelstein, B., 1990. A genetic model for colorectal tumorigenesis. Cell 61, 759-767.

Femia, A.P., Caderni, G., Ianni, M., Salvadori, M., Schijlen, E., Collins, G., Bovy, A., Dolara, P., 2003. Effect of diets fortified with tomatoes or onions with variable quercetin-glycoside content on azoxymethane-induced aberrant crypt foci in the colon of rats. Eur. J. Nutr. 42, 346-352.

Flohe, L., Gunzler, W.A., 1984. Assays of glutathione peroxidase. Methods Enzym. $105,114-121$.

Frajacomo, F.T., de Paula Garcia, W., Fernandes, C.R., Garcia, S.B., Kannen, V., 2015 Pineal gland function is required for colon antipreneoplastic effects of physica exercise in rats. Scand. J. Med. Sci. Sports 25, e451-e458.

Friedewald, W.T., Levy, R.I., Fredrickson, D.S., 1972. Estimation of the concentration of low-density lipoprotein cholesterol in plasma, without use of the preparative ultracentrifuge. Clin. Chem. 18, 499-502.

Garcia, S.B., Barros, L.T., Turatti, A., Martinello, F., Modiano, P., Ribeiro-Silva, A., Vespucio, M.V., Uyemura, S.A., 2006. The anti-obesity agent Orlistat is associated to increase in colonic preneoplastic markers in rats treated with a chemical carcinogen. Cancer Lett. 240, 221-224.

Inam, E., Ibanga, F., Essien, J., 2016. Bioaccumulation and cancer risk of polycyclic aromatic hydrocarbons in leafy vegetables grown in soils within automobile repair complex and environ in Uyo, Nigeria. Environ. Monit. Assess. 188, 681.

Iqbal, J., Hussain, M.M., 2009. Intestinal lipid absorption. American journal of physiology. Endocrinol. Metabolism 296, E1183-E1194.

Jeong, J.Y., Kamino, K., 1993. Lack of tumorigenic activity of 1,1-dimethylhydrazine in Syrian golden hamsters treated by subcutaneous injection. Exp. Toxicol. Pathol. 45, 61-63.

Kannen, V., Fernandes, C.R., Stopper, H., Zanette, D.L., Ferreira, F.R., Frajacomo, F.T., Carvalho, M.C., Brandao, M.L., Elias Junior, J., Jordao Junior, A.A., Uyemura, S.A., Waaga-Gasser, A.M., Garcia, S.B., 2013. Colon preneoplasia after carcinogen exposure is enhanced and colonic serotonergic system is suppressed by food deprivation. Toxicology 312, 123-131.

Kannen, V., Hintzsche, H., Zanette, D.L., Silva Jr., W.A., Garcia, S.B., WaagaGasser, A.M., Stopper, H., 2012a. Antiproliferative effects of fluoxetine on colon cancer cells and in a colonic carcinogen mouse model. PLoS One 7, e50043.

Kannen, V., Moreira, M.C., Waaga-Gasser, A.M., Modiano, P., Elias Junior, J. Fernandes, C.R., Garcia, S.B., 2014. Partial lipectomy reduces dimethylhydrazineinduced carcinogenic initiation in the colon of rats. Toxicology 316, 9-13.

Kannen, V., Zanette, D.L., Fernandes, C.R., Ferreira, F.R., Marini, T., Carvalho, M.C. Brandao, M.L., Elias Junior, J., Mauad, F.M., Silva Jr., W.A., Stopper, H., Garcia, S.B., 2012b. High-fat diet causes an imbalance in the colonic serotonergic system promoting adipose tissue enlargement and dysplasia in rats. Toxicol. Lett. 213 135-141.

Komutarin, T., Azadi, S., Butterworth, L., Keil, D., Chitsomboon, B., Suttajit, M. Meade, B.J., 2004. Extract of the seed coat of Tamarindus indica inhibits nitric oxide production by murine macrophages in vitro and in vivo. Food Chem. Toxicol. 42, 649-658.

Lim, C.Y., Mat Junit, S., Abdulla, M.A., Abdul Aziz, A., 2013. In vivo biochemical and gene expression analyses of the antioxidant activities and hypocholesterolaemic properties of Tamarindus indica fruit pulp extract. PLoS One 8, e70058.

Lobrich, M., Jeggo, P.A., 2007. The impact of a negligent G2/M checkpoint on genomic instability and cancer induction. Nat. Rev. Cancer 7, 861-869.

Maiti, R., Jana, D., Das, U.K., Ghosh, D., 2004. Antidiabetic effect of aqueous extract of seed of Tamarindus indica in streptozotocin-induced diabetic rats. J. Ethnopharmacol. 92, 85-91.

Martinello, F., Soares, S.M., Franco, J.J., Santos, A.C., Sugohara, A., Garcia, S.B. Curti, C., Uyemura, S.A., 2006. Hypolipemic and antioxidant activities from Tamarindus indica $L$. pulp fruit extract in hypercholesterolemic hamsters. Food Chem. Toxicol. 44, 810-818.

Maurin, N., Forgue-Lafitte, M.E., Levy, P., Zimber, A., Bara, J., 2007. Progression of tumors arising from large ACF is associated with the MUC5AC expression during rat colon MNNG carcinogenis. Int. J. Cancer 120, 477-483.

McLellan, E.A., Medline, A., Bird, R.P., 1991. Sequential analyses of the growth and morphological characteristics of aberrant crypt foci: putative preneoplastic lesions. Cancer Res. 51, 5270-5274.

Millen, A.E., Subar, A.F., Graubard, B.I., Peters, U., Hayes, R.B., Weissfeld, J.L., Yokochi, L.A., Ziegler, R.G., 2007. Fruit and vegetable intake and prevalence of colorectal adenoma in a cancer screening trial. Am. J. Clin. Nutr. 86, 1754-1764.

Moore, M.A., Thamavit, W., Ito, N., 1987. Comparison of lesions induced in the Syrian golden hamster by diethylnitrosamine, dimethylhydrazine, and 
dibutylnitrosamine: influence of subsequent butylated hydroxyanisole treatment. J. Natl. Cancer Inst. 78, 295-301.

Morales, P., Fujio, S., Navarrete, P., Ugalde, J.A., Magne, F., Carrasco-Pozo, C., Tralma, K., Quezada, M., Hurtado, C., Covarrubias, N., Brignardello, J., Henriquez, D., Gotteland, M., 2016. Impact of dietary lipids on colonic function and microbiota: an experimental approach involving orlistat-induced fat malabsorption in human volunteers. Clin. Transl. Gastroenterology 7, e161.

Mori, F., Della Rocca, C., Lazzaro, D., 2012. Metallothionein colon crypt immunopositivity as a rapid in vivo essay for drug efficacy studies. vivo 26, 693-702.

Nalini, N., Manju, V., Menon, V.P., 2006. Effect of spices on lipid metabolism in 1,2 dimethylhydrazine-induced rat colon carcinogenesis. J. Med. Food 9, 237-245.

Natukunda, S., Muyonga, J.H., Mukisa, I.M., 2016. Effect of tamarind (Tamarindus indica L.) seed on antioxidant activity, phytocompounds, physicochemical characteristics, and sensory acceptability of enriched cookies and mango juice. Food Sci. Nutr. 4, 494-507.

Ntanios, F.Y., Jones, P.J., 1999. Dietary sitostanol reciprocally influences cholestero absorption and biosynthesis in hamsters and rabbits. Atherosclerosis 143 , $341-351$.

Orthwein, A., Fradet-Turcotte, A., Noordermeer, S.M., Canny, M.D., Brun, C.M. Strecker, J., Escribano-Diaz, C., Durocher, D., 2014. Mitosis inhibits DNA doublestrand break repair to guard against telomere fusions. Science 344, 189-193.

Paoletti, F., Mocali, A., 1990. Determination of superoxide dismutase activity by purely chemical system based on NAD(P)H oxidation. Methods Enzym. 186, 209-220.

Paulsen, J.E., Steffensen, I.L., Namork, E., Hein, D.W., Alexander, J., 1996. Effect of acetylator genotype on 3,2'-dimethyl-4-aminobiphenyl induced aberrant crypt foci in the colon of hamsters. Carcinogenesis 17, 459-465.

Rajeshkumar, N.V., Kuttan, R., 2003. Modulation of carcinogenic response and antioxidant enzymes of rats administered with 1,2-dimethylhydrazine by Picroliv. Cancer Lett. 191, 137-143.

Ramos, A., Visozo, A., Piloto, J., Garcia, A., Rodriguez, C.A., Rivero, R., 2003. Screening of antimutagenicity via antioxidant activity in Cuban medicinal plants. J. Ethnopharmacol. 87, 241-246.

Razali, N., Mat Junit, S., Ariffin, A., Ramli, N.S., Abdul Aziz, A., 2015. Polyphenols from the extract and fraction of $T$. indica seeds protected HepG2 cells against oxidative stress. BMC Compl. Altern. Med. 15, 438.

Rimbau, V., Cerdan, C., Vila, R., Iglesias, J., 1999. Antiinflammatory activity of some extracts from plants used in the traditional medicine of north-African countries
(II). Phytother. Res. 13, 128-132.

Rosenberg, D.W., Giardina, C., Tanaka, T., 2009. Mouse models for the study of colon carcinogenesis. Carcinogenesis 30, 183-196.

Shi, J., Yang, B., Feng, P., Li, D., Zhu, J., 2010. Induction of apoptosis by tomato using space mutation breeding in human colon cancer SW480 and HT-29 cells. J. Sci. Food Agric. 90, 615-621.

Shivshankar, P., Shyamala Devi, C.S., 2004. Evaluation of co-stimulatory effects of Tamarindus indica $L$. on MNU-induced colonic cell proliferation. Food Chem. Toxicol. 42, 1237-1244.

Siegel, R., Desantis, C., Jemal, A., 2014. Colorectal cancer statistics, 2014. CA Cancer J. Clin. 64, 104-117.

Siegel, R., DeSantis, C., Virgo, K., Stein, K., Mariotto, A., Smith, T., Cooper, D., Gansler, T., Lerro, C., Fedewa, S., Lin, C., Leach, C., Cannady, R.S., Cho, H., Scoppa, S., Hachey, M., Kirch, R., Jemal, A., Ward, E., 2012. Cancer treatment and survivorship statistics, 2012. CA Cancer J. Clin. 62, 220-241.

Sudjaroen, Y., Haubner, R., Wurtele, G., Hull, W.E., Erben, G., Spiegelhalder, B. Changbumrung, S., Bartsch, H., Owen, R.W., 2005. Isolation and structure elucidation of phenolic antioxidants from Tamarind (Tamarindus indica L.) seeds and pericarp. Food Chem. Toxicol. 43, 1673-1682.

Toth, B., 1972. Morphological studies of angiosarcomas induced by 1,2-dimethylhydrazine dihydrochloride in Syrian golden hamsters. Cancer Res. 32, 2818-2827.

Tseng, T.H., Hsu, J.D., Chu, C.Y. Wang, C.J., 1996. Promotion of colon carcinogenesis through increasing lipid peroxidation induced in rats by a high cholesterol diet. Cancer Lett. 100, 81-87.

Vargas-Olvera, C.Y., Sanchez-Gonzalez, D.J., Solano, J.D., Aguilar-Alonso, F.A., Montalvo-Munoz, F., Martinez-Martinez, C.M., Medina-Campos, O.N., IbarraRubio, M.E., 2012. Characterization of N-diethylnitrosamine-initiated and ferric nitrilotriacetate-promoted renal cell carcinoma experimental model and effect of a tamarind seed extract against acute nephrotoxicity and carcinogenesis. Mol. Cell. Biochem. 369, 105-117.

Warnick, G.R., Benderson, J., Albers, J.J., 1982. Dextran sulfate-Mg2+ precipitation procedure for quantitation of high-density-lipoprotein cholesterol. Clin. Chem. 28, 1379-1388.

Zarbl, H., Sukumar, S., Arthur, A.V., Martin-Zanca, D., Barbacid, M., 1985. Direct mutagenesis of Ha-ras-1 oncogenes by N-nitroso-N-methylurea during initiation of mammary carcinogenesis in rats. Nature 315, 382-385. 